\title{
The origin of Oxalis corniculata L.
}

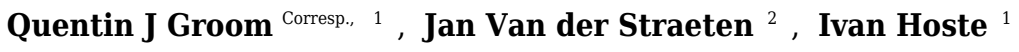 \\ 1 Meise Botanic Garden, Meise, Belgium \\ 2 \\ Laboratory of Plant Science and Nature Management, Vrije Universiteit Brussel, Brussels, Belgium \\ Corresponding Author: Quentin J Groom \\ Email address: quentin.groom@plantentuinmeise.be
}

Background. Oxalis corniculata L. is a weed with a world-wide distribution and unknown origin. Though it belong to a section of the genus from South American the evidence that this species came from there is weak.

Methods. We reviewed the evidence for the origin of $O$. corniculata using herbarium specimens, historic literature and archaeobotanical research. We also summarized ethnobotanical literature to understand where this species is most used by humans as a medicine.

Results. Despite numerous claims that it is native to Europe there is no strong evidence that $O$. corniculata occurred in Europe before the $15^{\text {th }}$ century. Nor is there reliable evidence that it occurred in North or South America before the $19^{\text {th }}$ century. However, there is direct archaeobotanical evidence of it occurring in South-east Asia at least 5000 years ago. There is also evidence from historic literature and archaeobotany that it reached Polynesia before European expeditions explored these islands.

Examination of the traditional use of $O$. corniculata demonstrates that is most widely used as a medicine in south-east Asia, which, while circumstantial, also point to a long association with human culture in this area.

Discussion. The most likely origin for $O$. corniculata is south-east Asia. This is consistent with a largely circum-Pacific distribution of section Corniculatae of Oxalis. Nevertheless, it is likely that $O$. corniculata spread to Europe and perhaps Polynesia before the advent of the modern era through trade routes at that time. 


\section{Title: The origin of Oxalis corniculata L.}

2

3 Running title: The origin of Oxalis corniculata $\mathrm{L}$.

4

\section{Quentin J. Groom ${ }^{1 *}$, Jan Van der Straeten ${ }^{2} \&$ Ivan Hoste $^{1}$}

1. Meise Botanic Garden, Meise, Belgium Belgium.

*corresponding author quentin.groom@plantentuinmeise.be

\section{Abstract} came from there is weak. trade routes at that time.

\section{Introduction}

2. Laboratory of Plant Science and Nature Management, Vrije Universiteit Brussel, Brussels,

Background. Oxalis corniculata L. is a weed with a world-wide distribution and unknown origin. Though it belong to a section of the genus from South American the evidence that this species

Methods. We reviewed the evidence for the origin of $O$. corniculata using herbarium specimens, historic literature and archaeobotanical research. We also summarized ethnobotanical literature to understand where this species is most used by humans as a medicine.

Results. Despite numerous claims that it is native to Europe there is no strong evidence that $O$. corniculata occurred in Europe before the $15^{\text {th }}$ century. Nor is there reliable evidence that it occurred in North or South America before the $19^{\text {th }}$ century. However, there is direct archaeobotanical evidence of it occurring in South-east Asia at least 5000 years ago. There is also evidence from historic literature and archaeobotany that it reached Polynesia before European expeditions explored these islands. Examination of the traditional use of $O$. corniculata demonstrates that is most widely used as a medicine in south-east Asia, which, while circumstantial, also point to a long association with human culture in this area.

Discussion. The most likely origin for $O$. corniculata is south-east Asia. This is consistent with a largely circum-Pacific distribution of section Corniculatae of Oxalis. Nevertheless, it is likely that O. corniculata spread to Europe and perhaps Polynesia before the advent of the modern era through

It is often stated that the origin of Oxalis corniculata L. is obscure or unknown. The species was first described by Carl Linnaeus from material from the Mediterranean region and some authors suggest that this region is the native range (Ridley, 1930; Young, 1968; Lourteig, 1979; Gray, 2011). Currently, O. corniculata has the third largest distribution of any vascular plant species (Pysek et al., 2017), having been introduced to practically every country. It has even been introduced to sub-Antarctic islands (Frenot et al., 2005). This global distribution and its relatively early spread have contributed to the difficulty of identifying its native range. Furthermore, it is almost constantly associated with anthropogenic disturbed habitats which makes its native range and the native status of local populations more difficult to determine. 
The designation of a native range can be important from a policy perspective, particularly where this relates to the control of invasive species and the avoidance of further spread. It is also required from a scientific perspective, to understand the evolution of section Corniculatae DC. of the genus Oxalis. Vaio et al. (2013) fixed the origin of section Corniculatae to South America using a molecular phylogenetic approach.

How this section subsequently colonized the world is an interesting question of evolution and dispersal. Molecular phylogenetics can only indicate where the ancestors of a taxon originate, but physical evidence is needed to establish where each taxon in that phylogeny is native. For most species the current distribution provides such physical evidence, but this is unreliable in a widely dispersed species such as $O$. corniculata. In some cases, by combining genetic and historical physical evidence the distributions of such species can been explained. For example, the New World distributions of the domestic dog (Canis lupus familiaris L., 1758) and the bottle gourd (Lagenaria siceraria (Molina) Standl.) have been explained this way (Savolainen et al., 2002; Erickson et al., 2005; Larson et al., 2012).

O. corniculata is highly persistent in the horticulture industry and is frequently found in gardens and as a hitchhiker in plant pots in nurseries and garden centres (Neal \& Derr, 2005). Its explosive capsules, sticky seeds, extended flowering period and short generation time make it a successful colonizer and persistent weed. Although it is not a strong competitor, its enormous range and abundance must multiple its overall impact as a weed. Furthermore, although $O$. corniculata is the weediest and most widespread of the species in the section Corniculatae, several other species in the section have spread beyond their native ranges. These include $O$. stricta L. and $O$. dillenii Jacq. from North America and O. exilis A.Cunn. from Australasia (Young 1968).

The taxonomy of $O$. corniculata is complex. It is variable cytologically and genetically, but is also phenotypically plastic (Mathew, 1958; Vaio et al., 2013). Its taxonomy is complicated by the description of many subspecific taxa and other species now considered to be synonyms (Lourteig, 1979). Its species limits vary depending on the authority, notably Eiten (1963) who tended to lump taxa and Lourteig (1979) who tended to split them. Furthermore, there has been taxonomic confusion of $O$. corniculata with closely related species, such as $O$. stricta and $O$. dillenii. In this paper we follow the nomenclature of Watson (1989) and Eiten (1963). One of the notable infraspecific taxa of $O$. corniculata is the purple-leaved variety atropurpurea of horticultural origin (Planchon, 1857).

Although much has been written about $O$. corniculata, the corpus has never been put together to form conclusions as to its origin. Here we review herbarium specimens, historic literature and archaeobotanical research to reach a conclusion on the biogeography of $O$. corniculata. Using herbarium specimens and literature we can document the presence and introduction of the species during the Modern Era. Archaeobotanical evidence helps us push the boundaries of our knowledge further back, but we also draw on other lines of evidence, some direct, some circumstantial.

\section{Methods}

First records of $O$. corniculata were gathered from the biodiversity literature and herbarium specimens. National and regional Floras were consulted, but also the literature indexed by the Biodiversity Heritage Library and the digitised manuscripts of the British Library. The monograph 
of Lourteig (1979) was also critical as she toured many of the major herbaria identifying specimens. For mapping earliest records we followed the specimens she identified as $O$. corniculata and its varieties, but excluded species such as $O$. radicosa A.Rich. and $O$. procumbens Steud. ex A.Rich. that may be included within $O$. corniculata by other authors. Many specimens and observations were also found by searching the Global Biodiversity Information Facility. However, due to the presence of related species, such as $O$. dillenii in North America and other species elsewhere, we treated observations in literature references cautiously if not combined with evidence.

A literature review on the ethnopharmacology of $O$. corniculata was conducted initially through Google Scholar, the Web of Science and the online catalogue of the library of Botanic Garden Meise, with searches on the key words 'oxalis', 'corniculata', 'medicinal', 'ethnobotany' and 'pharmacology'. A particular effort was to search ancient herbals for mentions of any plant that might be $O$. corniculata. Old Latin names for $O$. corniculata include Oxys luteo flore, Lotus urbana and Trifolium acetosum corniculatum, but there are also old vernacular names for Oxalis sp. such as alleluja, pain de coqu and sawerklee.

Each reference was documented, together with the ailment it was used to cure and the locality. Oxalis corniculata was reportedly used in the treatment of many ailments including diarrhoea, dysentery, fever, scurvy, stomach aches, wounds, snakebite and scorpion stings. Once the initial literature search was exhausted we used targeted searches including these ailments as keywords to find more references. Finally, every paper from 1979 onward in the Journal of Ethnopharmacology was reviewed for mentions of $O$. corniculata.

Localities for first records and ethnopharmacological uses were recorded using the level 4 codes in the World Geographical Scheme for Recording Plant Distributions (Brummitt, 2001). However, if the description of the locality was too indistinct the locality was recorded using the ISO 3166:1988 country codes.

\section{Results}

\section{A continental summary of the distribution of Oxalis corniculata}

\section{Europe and North Africa}

Europe has five extant species of Oxalis section Corniculatae, O. corniculata, O. exilis, O. stricta, $O$. dillenii and $O$. filiformis Kunth (syn. O. ferae L.Llorens, Gil \& C.Cardona). Of these, O. exilis and $O$. filiformis are $20^{\text {th }}$ century introductions with relatively narrow distributions (Llorens et al., 2005; Young, 1968). Owing to the presence of closely related species in Europe it is necessary to consider confusion of their identification in observations. Unless a complete specimen is available it is difficult to distinguish these taxa from one another, particularly if only fragments, such as seeds, are available. Taxonomic and nomenclatural confusion is a constant theme in the literature of this section (Eiten, 1955; Watson, 1989). Therefore, before investigating the situation of $O$. corniculata it is important to establish the time of introduction of $O$. stricta and $O$. dillenii to Europe.

It was not until 1680 that Morison described a species with an upright habit that we now refer to as $O$. stricta (Morison, 1680). However, this upright species was described from seed sent to him 
119 from Virginia and was not from Europe. By the mid-19th century the upright species (O. stricta) 120 was so well established in Europe that Jordan (1854) considered that it must be a native species 121 and described $O$. europaea Jord. He did so based purely on the geographic grounds that the 122 Linnaean $O$. stricta was North American. He did not give any morphological characters that 123 separate them. Herbarium specimens do exist of $O$. stricta collected in Europe before 1854, but 124 these are few and only date from earlier in the $19^{\text {th }}$ century (Table 1) (Lourteig, 1979).

125 O. dillenii was described and illustrated by Dillenius (1732) and was formally named later by 126 Jacquin (1794) with direct reference to Dillenius. However, this was from material of North 127 American origin. It was not until later that $O$. dillenii was recognised as naturalized in Europe. 128 Perhaps the first record is that of Jordan (1854) who named O. navieri Jord., which is now 129 considered a synonym for $O$. dillenii. Therefore, we agree with all modern authors that both $O$.

130 stricta and $O$. dillenii are $19^{\text {th }}$-century introductions and we can assume that earlier European observations of caulescent yellow-flowered Oxalis are of $O$. corniculata.

The earliest clear mention of a yellow-flowered caulescent Oxalis in European literature is from northern Italy in the $16^{\text {th }}$ century (Turner, 1568). The earliest herbarium specimens are also from northern Italy, from Florence in 1600 and Bologna between 1551 and 1600 (Table 1). Watson (1989) reviewed the taxonomic situation of $O$. corniculata in Europe and cites Renaissance botanists of the $16^{\text {th }}$ and $17^{\text {th }}$ century from Belgium, France, Germany, the Netherlands, Spain and Switzerland. Therefore, there is good evidence, including accurate drawings, that $O$. corniculata occurred in Europe at least from the $16^{\text {th }}$ century.

139 Earlier than this the information in literature is ambiguous. We have found four illustrations of 140 Oxalis (Alleluia or Panis Cuculi in Latin) in medieval herbals from the $13^{\text {th }}$ to $15^{\text {th }}$ centuries (Fig. 141 1). In each case only one taxa is illustrated. In Europe we would expect at least one taxon, the 142 native $O$. acetosella $\mathrm{L}$. This species is quite distinct from $O$. corniculata in having white flowers, 143 short globular pods, a scaly creeping rhizome and no stem. The illustration in the $15^{\text {th }}$ century 144 Codex Bellunensis has no flowers, but the scaly rhizome and lack of stem suggest this is $O$. 145 acetosella (Fig. 1c). The illustration in Giovanni Cadamosto's manuscript of the late $15^{\text {th }}$ or early $14616^{\text {th }}$ century ambiguously shows a part caulescent and part acaulescent plant (Fig. 1d). The flowers 147 of this illustration are in bud and are of little diagnostic use. Another herbal from circa 1440 shows 148 a caulescent Oxalis with small yellow flowers in umbels (Fig. 1b). This illustration is close to the 149 characters of $O$. corniculata and originates from Lombardy in northern Italy. Finally, the oldest 150 illustration is in the Tractatus de herbis (circa 1280-1350) (Fig 1a). This is a rather confusing illustration. It shows a horizontal creeping plant, rooting at the nodes, which could be $O$. acetosella 153 there are other four-pointed structures, which are presumably fruits. However, they do not 154 resemble Oxalis fruits.

155 A considerable number of archaeobotanical studies have been conducted in Europe, but remains 156 of Oxalis section Corniculatae remain rare. The RADAR database in the Netherlands contains 157 four records, the earliest of which are from a site that spans the $17^{\text {th }}$ and $18^{\text {th }}$ centuries (van Haaster 158 \& Brinkkemper 1995). In Ferrara, Italy, remains of a single seed were found in a waste pit dating 159 from the second half of the $15^{\text {th }}$ century, which is notable because of the pre-Columbian dating 160 (Bosi 2000, Bosi et al., 2009). Although a single seed, its location is close to the specimen, 
161 illustration and literature reports from the $15^{\text {th }}$ and $16^{\text {th }}$ centuries, giving credence to this isolated

162 observation. We have found no earlier archaeological evidence, even though some extensive

163 studies have been conducted. Rinaldi, Mazzanti \& Bosi (2013) summarize the seeds found in

164 excavations in Modena, in northern Italy from the $2^{\text {nd }}$ century BC to the $6^{\text {th }}$ century AD. They list

165 more than 400 taxa from 200,000 remains, including many weeds, but did not find O. corniculata.

166 Likewise a similar study in Lleida, Spain, covering the period between the $2^{\text {nd }}$ century BC and the

$16711^{\text {th }}$ century AD report no $O$. corniculata, despite recovering almost 600,000 seeds and fruits.

168 We have found two other archaeological reports of $O$. corniculata in Europe, one from Neolithic 169 Germany in the $6^{\text {th }}$ century BC and the other from Visigothic Spain in the $6^{\text {th }}-7^{\text {th }}$ century AD 170 (Herbig et al., 2013; Ollich, et al., 2014). The reports are only of two and one seed respectively 171 and there are no illustrations. Given the small number of seeds, the lack of supporting evidence

172 and the potential for later contamination or misidentification we have discounted these reports.

173 In all, we found no convincing evidence for the presence of $O$. corniculata in Europe earlier than 174 the $15^{\text {th }}$ century. Neither is there much information from North Africa, which has been in constant 175 communication with southern Europe for many centuries. Preserved Oxalis seeds have been 176 reported from late neolithic Hyrax middens in the Hoggar Mountains in the Sahara (Barakat, 177 1995). However, no illustration is provided and there is no way to verify this unlikely claim. A 178 more reliable source is from excavations at ancient Carthage in modern day Tunisia (van Zeist, 179 Bottema \& Van der Veen, 2001). Here, preserved Oxalis seeds were reported from sediment from 180 approximately the $4^{\text {th }}$ century BC to the mid- $6^{\text {th }}$ century AD. However, there is again no illustration 181 and we have been unable to access vouchers. The earliest direct observation from North Africa is 182 from 1751 (Hasselquist, 1766). This was near Damietta, Egypt, in the Nile delta.

183 In conclusion, there is good evidence of $O$. corniculata being in Europe from the $16^{\text {th }}$ century 184 onwards. Despite considerable taxonomic confusion, there is no evidence of $O$. stricta and $O$. 185 dillenii occurring here much before the beginning of the $19^{\text {th }}$ century, presumably as an 186 introduction from North America, as is generally assumed. Earlier than this, despite a copious 187 corpus of botanical, medicinal and archaeobotanical literature, the evidence is weak, leaving an 188 open question about the long-term existence of $O$. corniculata in Europe. The observation of $O$. 189 corniculata in Carthage may indicate that $O$. corniculata was present in the Mediterranean basin 190 during the Iron Age, though more evidence than this would be preferable. Therefore there is little 191 support for O. corniculata being native to Europe.

\section{Sub-Saharan Africa}

193 Today O. corniculata is a common weed in sub-Saharan Africa (Holm et al., 1991). However, 194 Vogel et al. (1849) specifically noted its absence from the western intertropical coast, where it is 195 present today (Hutchinson and Dalziel, 1954; Holm et al., 1991). The earliest sub-Saharan records 196 are of Thunberg from near Cape Town, South Africa, circa 1772 (Table 1). Thunberg described 197 its habitat as "Crescit prope urbem locis aquosis et in hortis" [Growing in wet ground near the city 198 gardens] (Thunberg, 1823). Thunberg described O. repens Thunb. from these specimens, which 199 has subsequently been synonymized with $O$. corniculata (Lourteig, 1979). The next specimens are 200 from the 1830s from South Africa and Ethiopia (Table 1), but there are few records from sub201 Saharan Africa until the $20^{\text {th }}$ century and many records are of $O$. corniculata as an agricultural 202 weed. 
203 In Ethiopia Richard, Petit \& Quartin-Dillon(1847) claimed three species, O. corniculata and two 204 new species $O$. procumbens and O. radicosa. Lourteig (1979) accepted O. procumbens and $O$. 205 radicosa as distinct species. Oxalis procumbens is said to grow in fields and fallow land at altitudes 206 above $1000 \mathrm{~m}$ in tropical Africa and O. radicosa has a larger distribution spanning much of Africa, 207 Asia and Australasia. Examples of specimens are in table 1. Many other authors, at least in Africa, 208 have treated these species as synonyms of O. corniculata (Engler, 1894; Madagascar Catalogue, 209 2017). If one accepts that $O$. procumbens and $O$. radicosa are distinct species in Africa, then there 210 is little reason to think that $O$. corniculata s.s. is native to sub-Saharan Africa. However, if these 211 species are considered to be part of $O$. corniculata s.s. then it is perhaps native to the east coast of

212 Africa and Madagascar and also to high altitude areas of tropical Africa. However, the lack of 213 systematic collecting in Africa before the $20^{\text {th }}$ century means that the indigenousness of specimens 214 attributed to $O$. procumbens and $O$. radicosa can also not be confirmed.

215 The lack of data from much of Africa make it difficult to draw conclusions and this is further 216 complicated by the ambiguity of the species concept of $O$. corniculata. The history of $O$. 217 corniculata in sub-Saharan Africa will probably remain obscure without further evidence or 218 discoveries.

\section{Australasia}

220 Australasia has several native species in section Corniculatae, but $O$. corniculata s.s. is considered

221

222

223

224

225

226

227

228

229

230 introduced (Webb, Sykes \& Garnock-Jones, 1988; Conn, Jeanes \& Richards, Richards 1999; Gray, 2011). Native taxa are O. novaecaledoniae R.Knuth \& Schltr., O. exilis, O. rubens Haw., $O$. perennans Haw., O. chnoodes Lourteig, O. radicosa A.Rich. and O. thompsoniae B.J.Conn \& P.G.Richards. Unlike authors of African floras, authors of Australasian floras accept $O$. radicosa as a distinct species. Australasian species live in a wide range of natural and anthropogenic habitats and although all are close in morphology to $O$. corniculata, all have distinct morphological features that separate them. Nevertheless, confusion of specimens and observations of $O$. corniculata with the native taxa must always be considered. Study of the Australasia situation is complicated because Eiten considered all Australasian members of the section Corniculatae to be part of $O$. corniculata s.l. and many specimens in herbaria retain his determinations (Eiten, 1963).

Of possible native species the closest species to O. corniculata in Australasia is $O$. thompsoniae that has recently been described (Conn \& Richards, 1994). It has a weedy habitat and is only known

233

234 from collections made from the late $20^{\text {th }}$ century. Conn and Richards (1994) suggest it may have been introduced to Australasia, but is of unknown origin. Likewise it may have evolved recently in Australasia from O. corniculata. Nevertheless, all reliable determinations of $O$. corniculata s.s. in Australasia date from the mid to late $20^{\text {th }}$ century.

237 In summary, the prevailing consensus that $O$. corniculata is a recent introduction to Australasia

238

239

240 seems to be consistent with the available evidence. However, the similarities of Australasian species with $O$. corniculata perhaps indicate a close evolutionary relationship. 
244 californica (Abrams) R.Knuth and O. texana (Small) Fedde. Furthermore, in Mexico, Central 245 America and the Caribbean there are other species, O. filiformis, O. rugeliana Urb. and $O$. 246 thelyoxys Focke (Nesom 2017).

247 O. corniculata s.s. is considered an introduction to North America (Nesom, 2009). In Central 248 America and the Caribbean the earliest herbarium specimens date from the 1820s (Lourteig, 1979). 249 However, an illustration in Hernández (1651) has been interpreted as being O. corniculata (Pico $250 \&$ Nuez, 2000), although the illustrated specimen cannot be confidently distinguished from other 251 North American taxa, such as O. albicans.

252 We found no evidence that conflicts with the widely held view that $O$. corniculata has been 253 introduced to North America.

254 South America

255 Several species in section Corniculatae have been reported in South America such as O. bisfracta, $256 O$. calachaccensis R.Knuth, $O$. corniculata, $O$. filiformis, $O$. rufescens Turcz. and $O$. sexenata 257 Savigny (Eiten, 1963). Also, others, such as $O$. dumetorum Barnéoud and $O$. conorrhiza Jacq. can 258 be included under a broader circumscription of section Corniculatae (Vaio et al., 2013).Vaio et 259 al. (2013) used a molecular phylogeny to trace the evolutionary roots of section Corniculatae to 260 South America. However, establishing whether O. corniculata s.s. is native to South America is 261 complicated because of the other closely related species present on the continent. Where 262 observations are not supported by specimens it is impossible to know if they have been correctly identified. The earliest specimens we have found of O. corniculata from South America (Brazil) are from 1815 to the 1830s (Table 1). However, in both cases the plants were either cultivated or weeds of cultivation.

266

267

268

269

270

271

272

273

274

275

276

277

278

279

280

281

282

283

Vaio et al. (2013) showed that $O$. corniculata is genetically close to the Bolivian species $O$. calachaccensis. In fact, $O$. calachaccensis does not possess any character that uniquely distinguishes it from O. corniculata (Eiten, 1963). Oxalis calachaccensis was described by Knuth (1915) using material he collected in 1911 from La Paz, Bolivia and one is left to assume it is native to that location. However, as Vaio et al. (2013) indicate, the taxonomic status of $O$. calachaccensis is doubtful.

No earlier literature or archaeobotanical evidence has been found for O. corniculata s.s in South America. Even though O. corniculata has South American ancestry, there is no evidence for the species being in South America before the $19^{\text {th }}$ century.

\section{Asia}

Oxalis corniculata is widespread in Asia and is an important weed in countries such as India and China (Reddy, 2008; Liu \& Watson, 2008). The authors of Asian Floras, such as those from China and Japan, do not commit to whether $O$. corniculata is native or introduced, but they conclude that the widespread dispersal by humans has made its origin obscure (Ōi, Meyer \& Walker, 1965; Liu $\&$ Watson, 2008).

Nevertheless, there are several archaeobotanical reports of $O$. corniculata seed from China. The earliest of these are from the Majiabang culture (Hunan, 7000-5800 BP; 16 seeds in two excavations) and Daxi culture (Jiangsu, 7000-5300 BP; 17 seeds) (Nasu et al., 2012; Qiu et al., 
284

285

286

287

288

289

290

291

292

293

294

295

296

297

298

299

300

301

302

303

304

305

306

307

308

309

310

311

312

313

314

315

316

317

318

319

320

321

322

323

2016). Then are reports from Henan Province 4950-4450 BP where 74 seeds were found (Deng et al., 2015). There are also reports of multiple preserved seed from the Huangguashan period in Fujian province from more than 3000 BP; from the Bronze Age in Yunnan province, and from during the Tang dynasty in Lantau (Atha 2012; Yao et al., 2015; Deng et al., 2017). The paper of Nasu et al. (2012) has a particularly convincing illustration of a seed. At all of these sites there was evidence of early agriculture where $O$. corniculata may have been a weed.

Apart from $O$. corniculata the only other possibility is that these are seeds of $O$. stricta, which is believed to be native to China (Liu \& Watson, 2008). However, this Flora of China describes $O$. stricta as growing in "Forests, ravines; 400-1500 m" in Guangxi, Hebei, Henan, Hubei, Jiangxi, Jilin, Liaoning, Shanxi, Zhejiang. This is not consistent with the presence of this Oxalis in either Hunan, Fujian, Yunnan or Jiangsu province as an agricultural weed.

Also in Asia, Oxalis seeds have been found in Japan from the Early Yayoi period (ca. 2820-2530 BP); in the Philippines in the $1^{\text {st }}$ millennium BC and in Vietnam between 3450 and 3250 BP (Paz, 2005; Nasu \& Momohara, 2016; Castillo et al., 2018). Castillo et al. (2018) provide a photograph of the single seed they found. Nasu \& Momohara (2016) indicate that they found between 11 and 58 seeds across two different excavations. Oxalis stricta has neither been found in the Philippines nor Vietnam, so it seems reasonable to assume these are seed of $O$. corniculata.

There is early documentary evidence of the presence of $O$. corniculata in China from 1751 (Osbeck, Torén \& Ekeberg,Ekeberg, 1771). This is from Guangdong, outside the known range of $O$. stricta in China and in a region where $O$. corniculata is common today. There is also a specimen from Osbeck in the Bergius Herbarium from 1751 and this has been identified by Lourteig as $O$. corniculata (Table 1). The distribution of first records illustrated in figure 2 demonstrates the cluster of early records from south-east Asia.

O. corniculata is also the main food plant of the larvae of Pseudozizeeria maha Kollar, 1844 (pale grass blue butterfly) (Saji et al., 2017). This species is found across India, southeast Asia, China, North and South Korea and Japan. The presence of this largely monophagous insect suggests that the original native range of its host plant lies within Asia.

While it is an indirect indication, the use of plants in traditional medicine can perhaps indicate a long association of a plant with human culture. In our survey of the medicinal uses of $O$. corniculata we discovered a total of 182 publications containing 892 remedies for ailments at different locations. It is evident from this map that Asia is at the centre of where O. corniculata is used medicinally (Fig. 3).

In conclusion, there are several high-quality paleobotanical records of $O$. corniculata in eastern Asia and early documentary evidence. Furthermore, there is at least one insect that feeds on $O$. corniculata in the continent and there is ample documentation of the use of $O$. corniculata in traditional Asian medicine. Therefore, there are several lines of evidence for $O$. corniculata having a long presence in Asia, although the association of $O$. corniculata with human disturbance and agriculture has probably led to its further spread within Asia. This makes it difficult to point to a more specific area of origin. However, the archaeobotanical remains from eastern China, Japan and the Philippines do point to a long history in this area. 


\section{Polynesia}

325 Oxalis corniculata was present on Hawaii (1779) and Tahiti (1769) when they were explored 326 during the scientific expeditions of Captain James Cook (St. John, 1978). Indeed, archaeological 327 excavations have found $O$. corniculata seed in sediment dated from between the $15^{\text {th }}$ and $17^{\text {th }}$ 328 centuries (McCoy, 1977; Allen, 1984). Therefore, O. corniculata is either native to Polynesia or, 329 as suggested by Ridley (1930), was introduced by Polynesian colonizers.

330

331

332

333

334

335

336

337

338

339

340

341

342

343

344

345

346

347

348

349

350

351

352

353

354

355

356

357

358

359

360

361

362

363

364

\section{Discussion}

The concept of native range is fluid and difficult to define precisely. It is hard to separate human activities from the supposed "natural" distribution of the organism, particularly when the term is used with agricultural weeds. Rather than define nativeness precisely we have merely tried to seek evidence for the presence of $O$. corniculata during its global colonization.

Vaio et al. (2013) provides us with a fixed origin for the section Corniculatae in South America, but the further speciation in Australasia and North America indicates that dispersal of the section to those continents occurred hundreds of thousands of years before present. Heibl \& Renner (2012) estimate that $O$. corniculata diverged from North American taxa (O. stricta and $O$. dillenii) about 10 million years ago. Therefore, there is no reason to presuppose that $O$. corniculata s.s. evolved in South America. Furthermore, additional resolution of the phylogeny of the section Corniculatae is needed. Vaio et al. (2013) did not include any of the known Australasian, Central American and Caribbean Corniculatae and only two of the North American species.

Although Europe has often been suggested as the origin of $O$. corniculata, there is no convincing evidence for its occurrence here earlier than the Renaissance. In contrast, there is clear evidence of $O$. corniculata in eastern Asia occurring for several thousand years. Archaeological evidence supports this conclusion. Furthermore, early specimens, literature and anthropogenic usage are consistent. This conclusion also makes sense regarding the proximity of its nearest relatives. These are native to Australasia, North America and South America. This means, if one accepts the eastern Asian origin of $O$. corniculata, that then Oxalis section Corniculatae has a largely circum-Pacific distribution, which we find rather more parsimonious than one member of the section naturally occurring in relative isolation in Europe.

There is undoubtedly considerable bias in the publication of ethnobotanical literature and in the intensity of collection of specimens from different parts of the world. In general, native plants are more often used in traditional medicines, but that is probably because there are more available (de Medeiros, Ladio \& Albuquerque, 2013). Plants are also specifically introduced for their medicinal properties. Nevertheless, these independent sources of evidence both focus on subtropical eastern Asia as an important region for $O$. corniculata. Although this evidence is weak these results are consistent with a native origin of $O$. corniculata in Asia and there is little support for an origin elsewhere.

The spread of $O$. corniculata into the Pacific islands with Polynesian voyagers is also consistent with an East Asian origin. Mitochondrial DNA and Y chromosome studies of Polynesians traces their origins back to Taiwan, the Philippines and Melanesia (Kayser et al., 2006; Ohashi et al., 2006). Indeed, a proposed spread of O. corniculata out of East Asia into the Pacific islands with early colonists could parallel the intentional introduction of Colocasia esculenta (L.) Schott (taro) 
365 to these island (Helmkampf et al., 2017). This, however, does not exclude natural dispersal 366 between islands (Aoyama, Kawakami \& Chiba, 2012).

367 Eiten (1963) suggested Australasia and south-east Asia as the area of origin of O. corniculata. 368 However, he did so for the wrong reasons. He supposed that the variability and broad geographic 369 spread of $O$. corniculata indicated that it was parental to the whole group, rather than a more newly 370 derived species as Vaio et al. (2013) have subsequently shown it to be. He also lumped all 371 Australasian specimens into $O$. corniculata s.l.

372 O. corniculata could have been an early introduction to Europe from the east. It may have occurred in Europe before the modern discovery of the New World. An obvious pathway would have been trade along the silk route, which has been suggested as a route of introduction for crops, weeds and plant diseases in both directions (Wei et al., 2008; Smith et al., 2014). We accept the presence of $O$. corniculata in Europe in the $15^{\text {th }}$ century, or it might have arrived earlier, during the period of the Pax Mongolica (13 $13^{\text {th }}-14^{\text {th }}$ centuries) and the reopening of the silk routes at this time. However, the possible earlier presence of $O$. corniculata in Carthage indicates an earlier introduction to the Mediterranean Basin. It is interesting that peach stones also occur in the Carthage deposits. Peaches (Prunus persica (L.) Batsch) were introduced to Europe by the $1^{\text {st }}$ century AD and peaches also have an Asian origin (Faust \& Timon, 1995). Coincidentally, it has also recently been suggested that taro was introduced to Europe in the $4^{\text {th }}$ century AD from Southeastern Asia (Grimaldi et al., 2018). Therefore, there are other examples of plants that have been transported between Asia and Europe for agriculture even before the $2^{\text {nd }}$ millennium.

The situation in sub-Saharan Africa is still unclear and may only be resolved once the taxonomic position of $O$. radicosa and $O$. procumbens has been established. In the case of South Africa, Cape Town was originally founded 1652 and was an important trading port for the Dutch East India Company during the $17^{\text {th }}$ and $18^{\text {th }}$ century. As such, it is not hard to envisage that $O$. corniculata was introduced there. Nevertheless, the testimony of floras indicates that even if $O$. corniculata was present in Africa before the modern era, it has become more common and today has a wider distribution than previously.

392 In South America the final difficulty is the status of $O$. calachaccensis, which is indistinguishable morphologically and genetically from $O$. corniculata. Its presence is Bolivia suggests that $O$. corniculata is either native to South America, or that the specimens described as $O$. calachaccensis are in fact introduced $O$. corniculata. Certainly, Knuth described $O$. calachaccensis from plants collected comparatively recently (Knuth, 1915). We are inclined to think that specimens described as $O$. calachaccensis are modern introductions and that $O$. calachaccensis should be considered a synonym of $O$. corniculata.

Relying upon physical evidence to determine the native origins of plant has its limitations and biases. A complementary method would be to examine the genetic diversity of $O$. corniculata globally. Taxa tend to be most genetically diverse in the area of their origin (Sakai et al., 2001) 402 and such an approach has been useful in understanding the invasion biology of $O$. pes-caprae L. 403 (Ferrero et al., 2015). It is hoped that such a study might be possible in the future if the difficulties 404 of collecting representative populations from six continents can be surmounted. Such a study 405 would further define the evolution and migration of this taxon worldwide. 


\section{Conclusions}

407 While many authors assume that the origin of $O$. corniculata is lost to time, we have shown that 408 there is sufficient evidence to conclude that it is in fact native to East Asia and unlikely to be native 409 to Europe. Many of the details of the global colonization by species of section Corniculatae remain 410 a mystery, particularly in Africa and Australasia. Furthermore, it is hoped that this paper will raise 411 awareness of the issues, so that new archaeological discoveries of $O$. corniculata remains are 412 recognised for their importance in understanding the biogeography of this species.

\section{Acknowledgements}

414 The authors would like to thank all the herbaria who helped with this project, including The Royal 415 Botanic Garden, Edinburgh; The Royal Botanic Garden, Kew and the Museum of Evolution, 416 Uppsala. A special word of thanks also goes to the Biodiversity Heritage Library, the British 417 Library and the Global Biodiversity Information Facility and their contributors for making such 418 research possible. We would also like to thank the reviewers for their insights and the care they 419 took in reviewing this paper.

\section{Data accessibility}

421 A reference list of ethnopharmacological uses and details of the source of first records are 422 deposited on Zenodo (Van der Straeten \& Groom, 2018; Groom, 2018).

\section{References}

424

425

426

427

428

429

430

431

432

433

434

435

436

437

438

439

440

441

442

Allen, M.S. (1984). A review of archaeobotany and palaeoethnobotany in Hawaii. Hawaiian Archaeology, 1, 19-30.

Aoyama, Y., Kawakami, K., \& Chiba, S. (2012). Seabirds as adhesive seed dispersers of alien and native plants in the oceanic Ogasawara Islands, Japan. Biodiversity and Conservation, 21, 2787-2801. DOI: 10.1007/s10531-012-0336-9

Atha, M. (2012). Archaeological Investigation at San Tau, Lantau Island. Unpublished report of investigation conducted on behalf of the Hong Kong Archaeological Society. http://www.hkarch.org/pdf/report/2011\%20Excavation\%20Report\%20for\%20HKAS\%202011\% 20Archaeological\%20Investigation\%20at\%20San\%20Tau,\%20Lantau\%20Island.pdf

Barakat, H.N. (1995). Plant macroremains from Z'bib N Elias. A subfossil middens from a prehistoric cave in the Hoggar, Central Sahara. Acta Palaeobotanica, 1, 99-103.

Bosi, G. (2000). Flora e ambiente vegetale a Ferrara tra il X e il XV secolo attraverso i reperti carpologici dello scavo di corso Porta Reno - via Vaspergolo nell'attuale centro storico. PhD Thesis, University of Florence, Italy.

Bosi, G., Mercuri. A.M., Guarnieri, C. \& Bandini Mazzanti, M. (2009) Luxury food and ornamental plants at the 15th century AD Renaissance court of the Este family (Ferrara, northern Italy). Vegetation History and Archaeobotany, 18, 389-402.

Brummitt, R.K. (2001). World Geographical Scheme for Recording Plant Distributions, Edition 2. Pittsburgh: Hunt Institute for Botanical Documentation Carnegie Mellon University. 
443 Castillo, C.C., Fuller, D.Q., Piper, P.J., Bellwood, P., \& Oxenham, M. (2018). Hunter-gatherer 444 specialization in the Late Neolithic of southern Vietnam-the case of Rach Nui. Quaternary

445 International. 489, 63-79.

446 Conn, B.J. \& Richards, P.G. (1994) A New Species of Oxalis Section Corniculatae

447 (Oxalidaceae) from Australasia. Australian Systematic Botany, 7, 171-181.

448 Conn, B.J., Jeanes, J.A., \& Richards, P.G. (1999). Oxalidaceae. In: Walsh NG, Entwisle TJ 449 (Eds) Flora of Victoria Vol. 4, Cornaceae to Asteraceae. Inkata Press, Melbourne.

450 de Medeiros, P.M., Ladio, A.H., \& Albuquerque, U. P. (2013). Patterns of medicinal plant use by 451 inhabitants of Brazilian urban and rural areas: A macroscale investigation based on available 452 literature. Journal of ethnopharmacology, 150(2), 729-746.

453 Deng, Z., Qin, L., Gao, Y., Weisskopf, A.R., Zhang, C. \& Fuller, D.Q. (2015) From Early 454 Domesticated Rice of the Middle Yangtze Basin to Millet, Rice and Wheat Agriculture:

455 Archaeobotanical Macro-Remains from Baligang, Nanyang Basin, Central China (6700-500 456 BC). PLoS ONE 10, e0139885. DOI: 10.1371/journal.pone.0139885

457 Deng, Z., Hung, H.C., Fan, X., Huang, Y., \& Lu, H. (2017). The ancient dispersal of millets in 458 southern China: New archaeological evidence. The Holocene, 28, 34-43. DOI:

$459 \quad \underline{10.1177 / 0959683617714603}$

460 Dillenius, J.J. (1732). Hortus Elthamensis seu Plantarum rariorum quas in horto suo Elthami in 461 Cantio coluit vir ornatissimus et praestantissimus Jacobus Sherard MD Soc. Reg. et Coll. Med. 462 Lond. Soc. Guilielmi P.M. frater, delineationes et descriptiones quarum historia vel plane non, 463 vel imperfecte a rei herbariae scriptoribus tradita fuit. Plantarum rariorum horti Elthamensis 464 tomus alter. London. http://bibdigital.rjb.csic.es/ing/Libro.php?Libro=1386

465 Eiten, G. (1955). The Typification of the Names "Oxalis corniculata L." and "Oxalis stricta L." 466 Taxon 4, 99-105. doi:10.2307/1216643

467 Eiten, G. (1963). Taxonomy and regional variation of Oxalis section Corniculatae. I.

468 Introduction, keys and synopsis of the species. The American Midland Naturalist, 69, 257-309. 469 DOI: $10.2307 / 2422912$

470 Engler, A. (1894). Diagnosen neuer Arten verschiedener Familien. Botanische Jahrbücher für 471 Systematik, Pflanzengeschichte und Pflanzengeographie, 19, 33.

472 https://biodiversitylibrary.org/page/204594

473 Erickson, D. L., Smith, B. D., Clarke, A. C., Sandweiss, D. H., \& Tuross, N. (2005). An Asian 474 origin for a 10,000-year-old domesticated plant in the Americas. Proceedings of the National 475 Academy of Sciences, 102(51), 18315-18320.

476 Faust, M., \& Timon, B. (1995). Origin and dissemination of peach. In: Horticultural Reviews J. 477 Janick (Ed.) 17, 331-379. DOI: 10.1002/9780470650585.ch10

478 Ferrero, V., Barrett, S. C., Castro, S., Caldeirinha, P., Navarro, L., Loureiro, J., \& 479 Rodríguez-Echeverría, S. (2015). Invasion genetics of the Bermuda buttercup (Oxalis 480 pes-caprae): complex intercontinental patterns of genetic diversity, polyploidy and heterostyly 481 characterize both native and introduced populations. Molecular ecology, 24(9), 2143-2155. 
482 Frenot, Y., Chown, S.L., Whinam, J., Selkirk, P.M., Convey, P., Skotnicki, M., \& Bergstrom, 483 D.M. (2005). Biological invasions in the Antarctic: extent, impacts and implications. Biological 484 Reviews, 80, 45-72. DOI: 10.1017/S1464793104006542

485 Gray, A.M. (2011). 70 Oxalidaceae, version 2011:1. In MF Duretto (Ed.) Flora of Tasmania 486 Online. 8 pp. Tasmanian Herbarium, Tasmanian Museum \& Art Gallery. Hobart.

487 www.tmag.tas.gov.au/floratasmania

488 Grimaldi, I.M., Muthukumaran. S., Tozzi, G., Nastasi, A., Boivin, N., Matthews, P.J. \& van

489 Andel, T. (2018) Literary evidence for taro in the ancient Mediterranean: A chronology of names 490 and uses in a multilingual world. PLOS ONE 13(6), e0198333. DOI:

$491 \quad 10.1371 /$ journal.pone.0198333

492 Groom, Q. (2018). Earliest records of Oxalis corniculata by country (Version 1) [Data set].

493 Zenodo. DOI: 10.5281/zenodo.1332025

494 Hasselquist, F. (1766.) Voyages and travels in the Levant. L. Davis and C. Reymers, London.

495 DOI: $10.5962 /$ bhl.title.47016

496 Heibl, C., \& Renner, S. S. (2012). Distribution models and a dated phylogeny for Chilean Oxalis 497 species reveal occupation of new habitats by different lineages, not rapid adaptive radiation.

498 Systematic Biology, 61(5), 823-834. DOI: 10.1093/sysbio/sys034

499 Helmkampf, M., Wolfgruber, T.K., Bellinger, M.R., Paudel, R., Kantar, M.B., Miyasaka, S.C.,

500 Kimball, H.L., Brown, A., Veillet, A., Read, A. \& Shintaku, M. (2017). Phylogenetic

501 relationships, breeding implications, and cultivation history of Hawaiian taro (Colocasia

502 esculenta) through genome-wide SNP genotyping. Journal of Heredity, 109, 272-282. DOI:

$503 \quad 10.1093 /$ ihered/esx070

504 Herbig, C., Maier, U., Stäuble, H., \& Elburg, R. (2013). Neolithische Füllhörner.

505 Archäobotanische Untersuchungen an fünf linienbandkeramischen Brunnen in Westsachsen. In:

506 Von Carnap-Bornheim C, Dörfler W, Kirleis W, Müller J, Müller U (eds) Von Sylt bis Kastanas.

507 Festschrift Kroll. Offa, 69, 265-293.

508 Hernández, F. (1651) Rerum Medicarum Novae Hispaniae Thesaurus. Vol. 1-4. Instituto

509 poligrafico e zecca dello stato. Libraria dello stato, Roma, Italy. DOI: 10.5962/bhl.title.136937

510 https://biodiversitylibrary.org/page/54114589

511 Holm, L.G., Pancho, J.V., Herberger, J.P., \& Plucknett, D.L. (1991). A Geographic Atlas of

512 World Weeds. Malabar, Florida, USA: Krieger Publishing Company.

513 Hutchinson, J., \& Dalziel, J.M. (1954). Flora of West Tropical Africa. Vol. 1, Part 1, Crown

514 Agents for Oversea Governments and Administrations, London.

515 Jacquin, N.J. (1794) Oxalis. Monographia, Iconibus Illustrata. Christianum F. Wappler, Vienna.

516 DOI: $10.5962 /$ bhl.title.888

517 Jordan, A. (1854). Notes sur diverses espèces. pp. 304-325. Archives de la Flore de France \&

518 d'Allemagne : Publiés par Friedr. Schultz; eds Schultz, Friedr. Bitche, Haguenau, Deux-Ponts 
519 Kayser, M., Brauer, S., Cordaux, R., Casto, A., Lao, O., Zhivotovsky, L.A., Moyse-Faurie, C., 520 Rutledge, R.B., Schiefenhoevel, W., Gil, D., Lin, A.A., Underhill, P.A., Oefner, P.J., Trent, R.J., 521 \& Stoneking, M. (2006). Melanesian and Asian Origins of Polynesians: MtDNA and Y

522 Chromosome Gradients Across the Pacific. Molecular Biology and Evolution, 23, 2234-2244.

523 DOI: 10.1093/molbev/ms1093

524 Knuth, R.G.P. (1915). Oxalidaceae In: Herzog T (Ed) Die von Dr. Th. Herzog auf seiner zweiten 525 Reise durch Bolivien in den Jahren 1910 und 1911 gesammelten Pflanzen. Mededeelingen van's 526 Rijks-Herbarium. Leiden, 27, 1-90. https://biodiversitylibrary.org/page/13684455

527 Larson, G., Karlsson, E. K., Perri, A., Webster, M. T., Ho, S. Y., Peters, J., Stahl, P.W., Piper, 528 P.J., Lingaas, F., Fredholm, M., Comstock, K.E., Modiano, J.F. Schelling, C., Agoulnik, .I., 529 Leegwater, P.A., Dobney, K., Vigne, J-D., Vilà, C., Leif Andersson, L. \& Lindblad-Toh, K. 530 (2012). Rethinking dog domestication by integrating genetics, archeology, and biogeography. 531 Proceedings of the National Academy of Sciences, 109(23), 8878-8883.

532 Llorens, L., Gil, L., Cardona, C., Franquesa, M., \& Boi, M. (2005). A new species of Oxalis 533 section Corniculatae (Oxalidaceae) from the Balearic islands. Botanical Journal of the Linnean 534 Society, 148, 489-493. DOI: 10.1111/j.1095-8339.2005.00408.x

535 Liu, Q., \& Watson, M. (2008). Oxalidaceae. In: Flora of China Vol. 11

536 http://www.efloras.org/florataxon.aspx?flora_id=2\&taxon_id=10644

537 Lourteig, A. (1979). Oxalidaceae extra-austroamericanae: 2. Oxalis L. Sectio Corniculatae DC.

538 Phytologia, 42, 57-198. https://www.biodiversitylibrary.org/part/38832

539 Madagascar Catalogue (2017). Catalogue of the Vascular Plants of Madagascar. Missouri

540 Botanical Garden, St. Louis, U.S.A. \& Antananarivo, Madagascar

541 http://www.tropicos.org/Project/Madagascar [accessed: December, 2017].

542 Mathew, P.M. (1958). Cytology of Oxalidaceae. Cytologia, 23, 200-210. DOI:

$543 \quad 10.1508 /$ cytologia.23.200

544 McCoy, P. (1977). The Mauna Kea adze quarry project: a summary of the 1975 field 545 investigations. The Journal of the Polynesian Society 86, 223-244.

546 http://www.jstor.org/stable/20705251

547 Morison, R. (1680). Plantarum Historiae Universalis Oxoniensis pars Secunda. Oxford.

548 http://bibdigital.rjb.csic.es/ing/Libro.php?Libro=5551

549 Nasu, H., Gu, H.B., Momohara, A., \& Yasuda, Y. (2012). Land-use change for rice and foxtail 550 millet cultivation in the Chengtoushan site, central China, reconstructed from weed seed 551 assemblages. Archaeological and Anthropological Sciences, 4, 1-14. DOI: 10.1007/s12520$552 \quad \underline{011-0077-9}$

553 Nasu, H., \& Momohara, A. (2016). The beginnings of rice and millet agriculture in prehistoric 554 Japan, Quaternary International, 397, 504-512. DOI: 10.1016/j.quaint.2015.06.043

555 Neal, J.C., \& Derr, J.F. (2005). Weeds of container nurseries in the United States. North Carolina 556 association of Nurserymen. 0-89892-312-3 
557 Nesom, G.L. (2009). Again: taxonomy of yellow-flowered caulescent Oxalis (Oxalidaceae) in 558 eastern North America. Journal of the Botanical Research Institute of Texas, 3(2), 727-738. 559 https://biodiversitylibrary.org/page/41537063

560 Nesom, G.L. (2017) Oxalidaceae. In: Flora of North America Vol. 12, pp. 113-153 Oxford 561 University Press, New York.

562 Ohashi, J., Naka, I., Tokunaga, K., Inaoka, T., Ataka, Y., Nakazawa, M., Matsumura, Y., \&

563 Ohtsuka, R. (2006). Brief communication: mitochondrial DNA variation suggests extensive gene

564 flow from Polynesian ancestors to indigenous Melanesians in the northwestern Bismarck

565 Archipelago. American Journal of Physical Anthropology, 130, 551-556. DOI:

$566 \quad \underline{10.1002 / a j p a .20383}$

567 Ōi, J., Meyer, F.G. \& Walker, E.H. (1965). Flora of Japan. Smithsonian Institution. DOI:

$568 \quad \underline{10.5962 / \text { bhl.title. } 43786}$

569 Ollich, I., Cubero, C., Ocaña, M. \& Rocafiguera, M.D. (2014). Arqueobotànica i Arqueologia

570 Experimental. 20 anys de recerca agrícola a l'Esquerda (Roda de Ter, Osona). Tribuna

571 d'Arqueologia. 20: 295-316. ISSN 1130-7781

572 Osbeck, P., Torén, O., \& Ekeberg, C.G. (1771). A voyage to China and the East Indies (Vol. 1).

573 B. White, 1-396.

574 Paz, V. (2005) Rock shelters, caves, and archaeobotany in Island Southeast Asia. Asian

575 Perspectives, 44, 107-118.

576 Pico, B., \& Nuez, F. (2000). Minor crops of Mesoamerica in early sources (I). Leafy vegetables.

577 Genetic Resources and Crop Evolution, 47, 527-540. DOI: 10.1023/A:1008704110054

578 Planchon, J.E. (1857). Oxalis corniculata L. var. atropurpurea. Flore des serres et des jardins de

579 l'Europe, 12, 47-48. https://biodiversitylibrary.org/page/27803658

580 Pyšek, P., Pergl, J., Essl, F., Lenzner, B., Dawson, W., Kreft, H., Weigelt, P., Winter, M.,

581 Kartesz, J., Nishino, M., Antonova, L.A., Barcelona, J.F., Cabezas, F.J., Cárdenas, D., Cárdenas-

582 Toro, J., Castańo, N., Chacón, E., Chatelain, C., Dullinger, S., Ebel, A.L., Figueiredo, E.,

583 Fuentes, N., Genovesi, P., Groom, Q.J., Henderson, L., Inderjit, Kupriyanov, A., Masciadri, S.,

584 Maurel, N., Meerman, J., Morozova, O., Moser, D., Nickrent, D., Nowak, P.M., Pagad, S.,

585 Patzelt, A., Pelser, P.B., Seebens, H., Shu, W., Thomas, J., Velayos, M., Weber, E., Wieringa,

586 J.J., Baptiste, M.P., \& van Kleunen, M. (2017). Naturalized alien flora of the world: species

587 diversity, taxonomic and phylogenetic patterns, geographic distribution and global hotspots of

588 plant invasion. Preslia, 89, 203-274. DOI: 10.23855/preslia.2017.203

589 Qiu, Z.W., Liu, B.S., Li, Y.Q., Shang, X., \& Jiang, H.E. (2016). Analysis of plant remains at the

590 Neolithic Yangjia Site, Wuxi City, Jiangsu Province (East China). Science China Earth Sciences,

591 59, 1803-1816. DOI: $10.1007 / \mathrm{s} 11430-016-5326-4$

592 Reddy, C.S. (2008). Catalogue of invasive alien flora of India. Life science journal, 5, 84-89.

593 Richard, A., Petit, A., \& Quartin-Dillon, M. (1847). Tentamen florae Abyssinicae

594 1: 122-124. Paris: Arthus Bertrand http://www.biodiversitylibrary.org/item/7776 
595 Ridley, H.N. (1930). The dispersal of plants throughout the world. L. Reeve \&

596 Co., Ashford.

597 Rinaldi, R., Mazzanti, M.B., \& Bosi, G. (2013). Archaeobotany in urban sites: the case of

598 Mutina. Annali di Botanica, 3, 217-230. DOI: 10.4462/annbotrm-10292

599 Saji, K., Haneesh, K.M., Soman, A. \& Kanwal, A. (2017). Pseudozizeeria maha Kollar, 1844 -

600 Pale Grass Blue. Kunte K, Sondhi S, Roy P (Eds.). Butterflies of India, v. 2.28. Indian

601 Foundation for Butterflies.

602 http://www.ifoundbutterflies.org/sp/607/Pseudozizeeria-maha

603 Sakai, A. K., Allendorf, F. W., Holt, J. S., Lodge, D. M., Molofsky, J., With, K. A., Baughman,

604 S., Cabin, R.J., Cohen, J.E., Ellstrand, N.C., McCauley, D. E., O'Neil, P., Parker, I.M.,

605 Thompson, J.N. \& Weller, S.G. (2001). The population biology of invasive species. Annual

606 review of ecology and systematics, 32(1), 305-332. DOI:

$607 \quad$ 10.1146/annurev.ecolsys.32.081501.114037

608 Savolainen, P., Zhang, Y. P., Luo, J., Lundeberg, J., \& Leitner, T. (2002). Genetic evidence for 609 an East Asian origin of domestic dogs. Science, 298(5598), 1610-1613. DOI:

$610 \quad 10.1126 /$ science. 1073906

611 Smith, O., Clapham, A., Rose, P., Liu, Y., Wang, J., \& Allaby, R.G. (2014). A complete ancient 612 RNA genome: identification, reconstruction and evolutionary history of archaeological Barley

613 Stripe Mosaic Virus. Scientific reports, 4, 4003. DOI: 10.1038/srep04003

614 St John, H. (1978). The first collection of Hawaiian plants by David Nelson in 1779. Hawaiian

615 plant studies 55. Pacific Science, 32, 315-324. http://hdl.handle.net/10125/1441

616 Thunberg, C.P. (1823). Flora capensis Vol. 2. J. F. Edman. DOI: 10.5962/bhl.title.6711

617 Turner, W. (1568). The First and Second Partes of the Herbal of William Turner in Phisick. part 618 2: Collen.

619 van Haaster, H., \& Brinkkemper, O. (1995). RADAR, a relational archaeobotanical database for 620 advanced research. Vegetation History and Archaeobotany, 4, 117-125. DOI:

$621 \quad 10.1007 / \mathrm{BF} 00206920$

622 Vaio, M., Gardner, A., Emshwiller, E., \& Guerra, M. (2013). Molecular phylogeny and 623 chromosome evolution among the creeping herbaceous Oxalis species of sections Corniculatae

624 and Ripariae (Oxalidaceae). Molecular Phylogenetics and Evolution, 68, 199-211. DOI:

625 10.1016/j.ympev.2013.03.019

626 Van der Straeten, J., \& Groom, Q. (2018). A bibliography of the medicinal uses of Oxalis

627 corniculata [Data set]. Zenodo. DOI: 10.5281/zenodo.1254000

628 van Zeist, W., Bottema, S., \& Van der Veen, M. (2001). Diet and vegetation at ancient

629 Carthage: the Archaeobotanical evidence. Groningen: Groningen Institute of Archaeology.

630 Watson, M.F. (1989). Nomenclatural aspects of Oxalis section Corniculatae in Europe.

631 Botanical Journal of the Linnean Society, 101, 347-362. DOI: 10.1111/j.1095-

632 8339.1989.tb00169.x 
633 Webb, C.J., Sykes, W.R., \& Garnock-Jones, P.J. (1988). Flora of New Zealand. Vol. IV. 634 Naturalised Pteridophytes, Gymnosperms, Dicotyledons. Botany Division DSIR, Christchurch.

635 Wei, H., Li, J., Peng, Z., Lu, B., Zhao, Z., \& Yang, W. (2008). Relationships of Aegilops tauschii 636 revealed by DNA fingerprints: The evidence for agriculture exchange between China and the 637 West. Progress in Natural Science, 18, 1525-1531. DOI: 10.1016/j.pnsc.2008.05.022

638 Yao, A., Jiang, Z., Chen, X., \& Liang, Y. (2015). Bronze age wetland/scapes: complex political 639 formations in the humid subtropics of southwest China, 900-100 BC. Journal of 640 Anthropological Archaeology, 40, 213-229. DOI: 10.1016/j.jaa.2015.08.005

641 Young, D.P. (1968). Oxalidaceae. In: Valentine DH (Eds) Flora Europeae 2. Cambridge 642 University Press, Cambridge. 192-193. 


\section{Figure 1}

Medieval illustrations of Oxalis from Europe

Medieval illustrations of Oxalis from herbals of the period. (a) The Tractatus de herbis attributed to Bartholomæus Mini de Senis, (c. 1280-1350). (b) An anonymous herbal circa 1440 from Northern Italy. (c) The Codex Bellunensis from the early $15^{\text {th }}$ century. (d) Giovanni Cadamosto's Herbal with treatises on food, poisons and remedies, and the properties of stones from the end of the 15th century or beginning of the 16th century. Access to these manuscripts available through the British Library. Shelfmark and folio: Egerton 747 f.12;

Sloane 4016 f.15r; Add 41623 f.14v; Harley 3736 f.2v

(http://www.bl.uk/manuscripts/Default.aspx). 

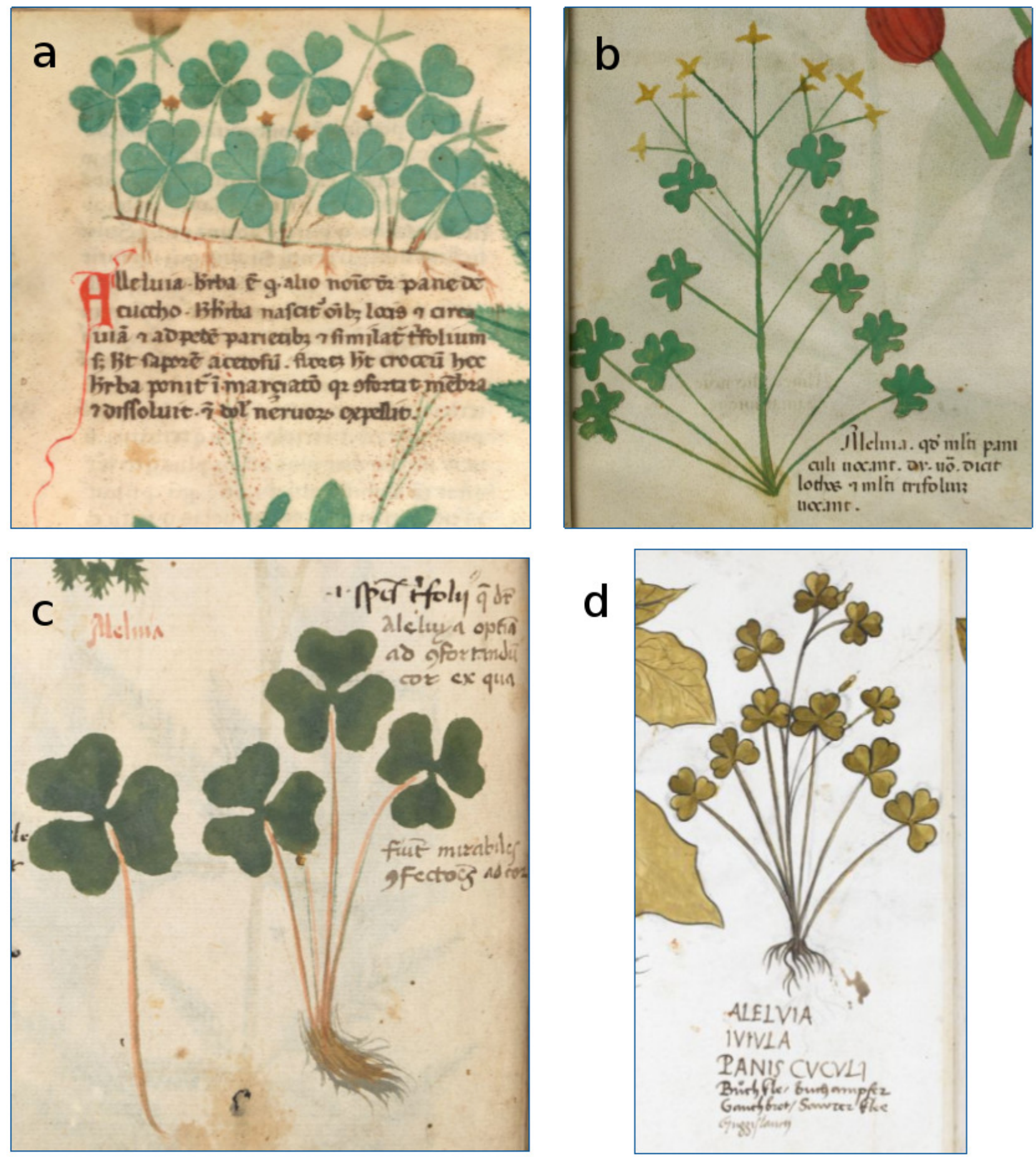
Figure 2

First observations of Oxalis corniculata

First observations of Oxalis corniculata globally based upon herbarium specimens, historic literature and paleobotanical research. The map uses the World Geographical Scheme for Recording Plant Distributions (Brummitt, 2001). Areas were no records were discovered are coloured in green. Note that the scale used is non-linear to allow visualization of the differences in modern introduction dates. The map uses a Mollweide projection. Details of these records have been deposited in an open repository (Groom, 2018).

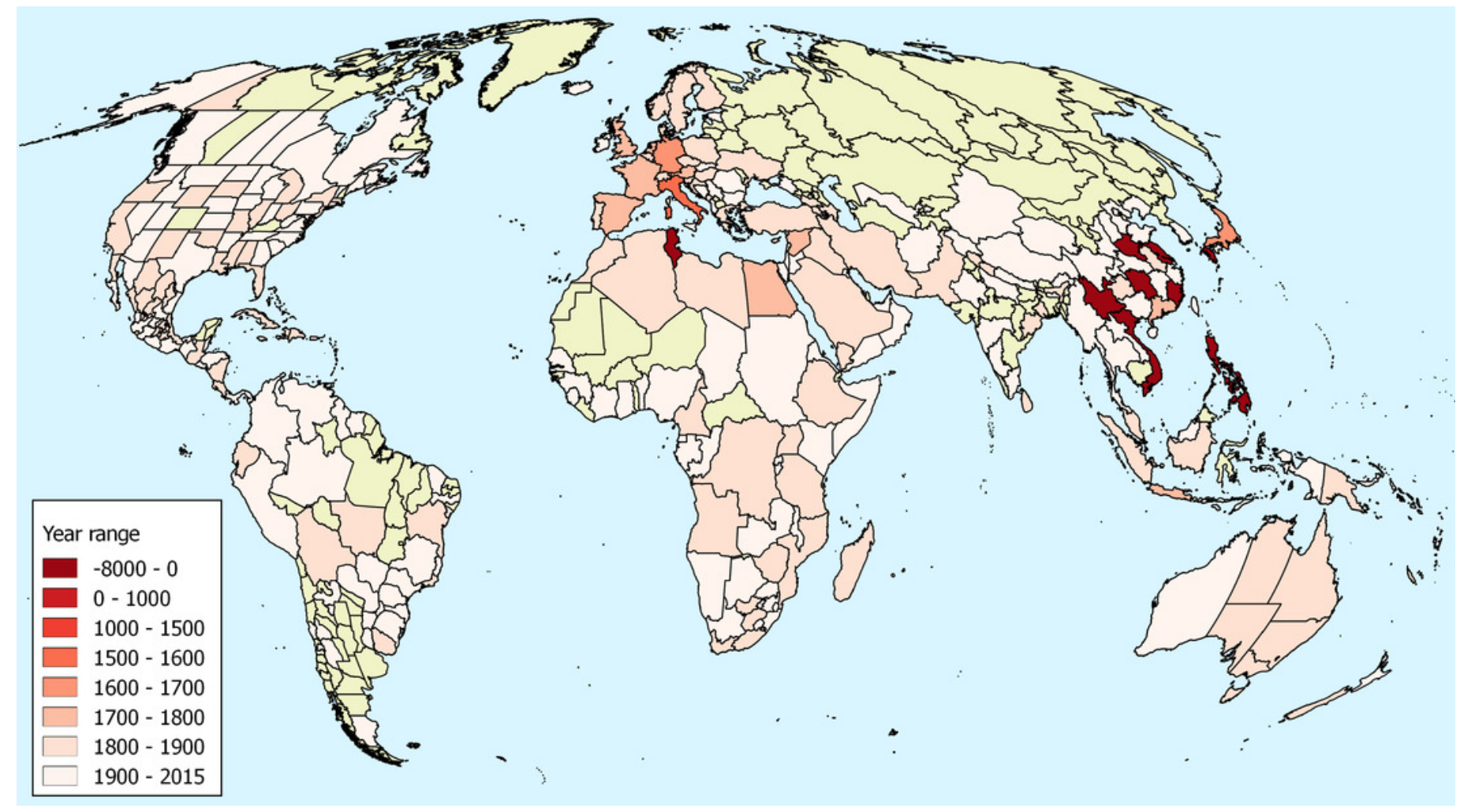


Figure 3

The number of ethnopharmacological citations

The number of ethnopharmacological citations for the uses of Oxalis corniculata. Areas with no reports of usage are coloured in green. The map uses the World Geographical Scheme for Recording Plant Distributions (Brummitt, 2001). The map uses a Mollweide projection.

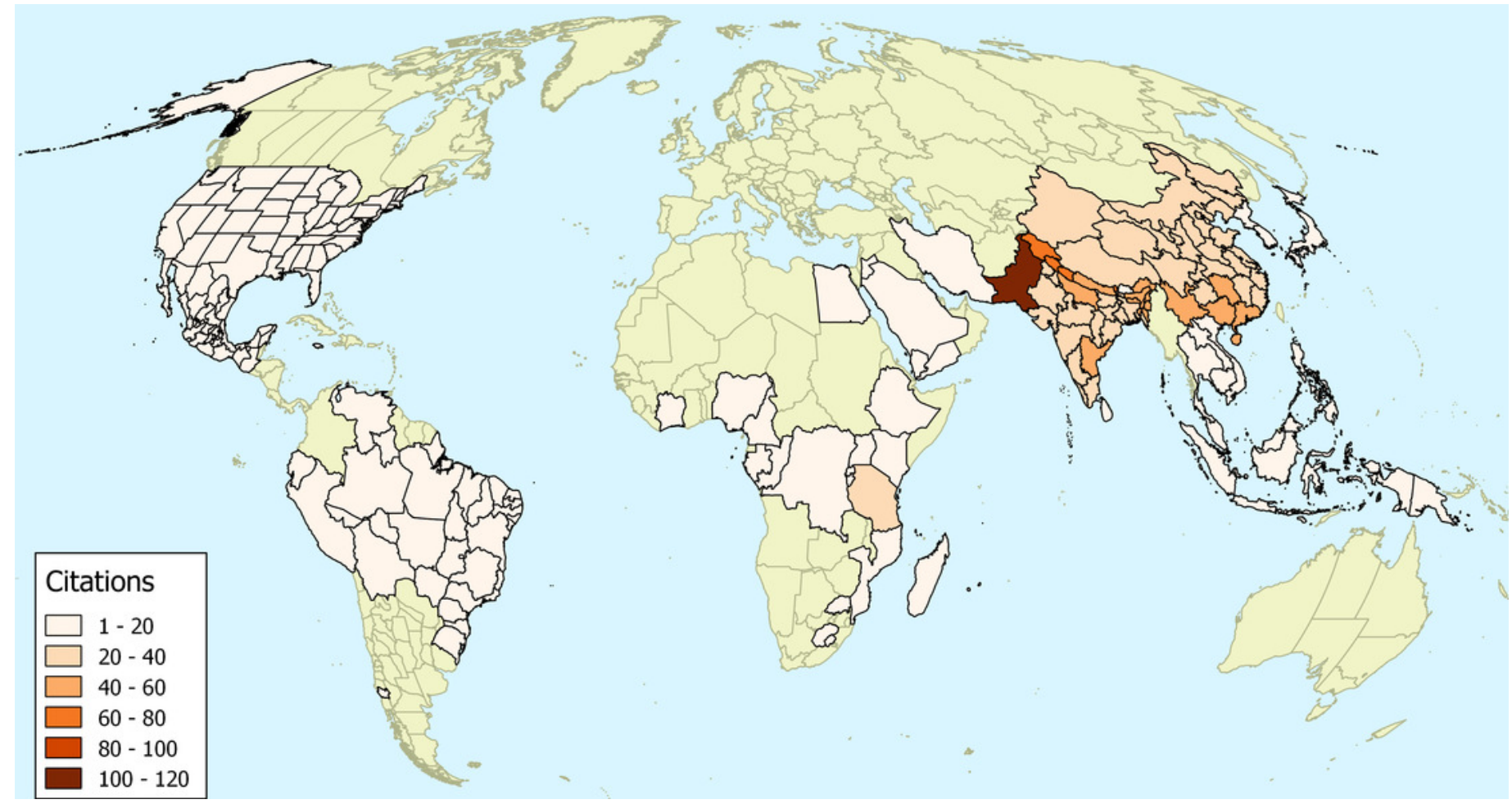




\section{Table $\mathbf{1}$ (on next page)}

Notable early specimens of Oxalis corniculata and O. stricta.

Cited and early specimens of Oxalis section Corniculatae from Europe, Africa, South America and China. N.B. O. europea, which was described from European specimens, is considered a synonym of $O$. stricta, which was described from North American material. 
1 Table 1. Cited and early specimens of Oxalis section Corniculatae from Europe, Africa, South America and China.

\begin{tabular}{|c|c|c|c|c|c|c|}
\hline Taxon & $\begin{array}{c}\text { Collector Name } \\
\text { and No. }\end{array}$ & $\begin{array}{l}\text { Collector } \\
\text { Number }\end{array}$ & Date & Country & $\begin{array}{l}\text { Catalogue number \& } \\
\text { HTTP URI }\end{array}$ & Notes \\
\hline Oxalis stricta $\mathrm{L}$. & C.E.Broome & s.n. & 1836 & Belgium & $\begin{array}{l}\text { http://data.rbge.org.u } \\
\text { k/herb/E00874849 }\end{array}$ & $\begin{array}{l}\text { An example of a European specimen } \\
\text { collected before } O \text {. europaea Jord, was } \\
\text { described. }\end{array}$ \\
\hline Oxalis stricta $\mathrm{L}$. & s.c. & s.n. & 1835 & Germany & $\begin{array}{l}\text { http://data.rbge.org.u } \\
\text { k/herb/E00874850 }\end{array}$ & $\begin{array}{l}\text { An example of a European specimen } \\
\text { collected before } O \text {. europea Jord, was } \\
\text { described. }\end{array}$ \\
\hline Oxalis corniculata $\mathrm{L}$. & Joachim Burser & s.n. & 1600 & Italy & $\begin{array}{l}\text { UPS:BOT:V-175221 } \\
\text { http://www.gbif.org/ } \\
\text { occurrence/3281931 } \\
\text { 49/verbatim }\end{array}$ & An early specimen from Europe. \\
\hline Oxalis corniculata L. & Ulisse Aldrovandi & s.n. & $1551-1600$ & Italy & Volume 8, page 134 & An early specimen from Europe. \\
\hline Oxalis corniculata $\mathrm{L}$. & $\begin{array}{l}\text { Carl Peter } \\
\text { Thunberg }\end{array}$ & 11118 & $1772-1775$ & $\begin{array}{l}\text { South } \\
\text { Africa }\end{array}$ & UPS:BOT:V-086842 & $\begin{array}{l}\text { The earliest specimen from sub-Sahara } \\
\text { Africa. (Lectotype of } O \text {. repens Thunberg) }\end{array}$ \\
\hline Oxalis corniculata L. & $\begin{array}{l}\text { Christian Friedrich } \\
\text { Ecklon \& Carl L.P. } \\
\text { Zeyher }\end{array}$ & s.n. & 1830 & $\begin{array}{l}\text { South } \\
\text { Africa }\end{array}$ & $\begin{array}{l}\text { PRE0453493-0 } \\
\text { https://www.gbif.org } \\
\text { /occurrence/4621220 } \\
48\end{array}$ & An early specimen from South Africa. \\
\hline
\end{tabular}




\begin{tabular}{|c|c|c|c|c|c|c|}
\hline $\begin{array}{l}\text { Oxalis corniculata L.(as } \\
\text { O. procumbens Steud.) }\end{array}$ & Wilhelm Schimper & 1165 & $1838-02-05$ & Ethiopia & $\begin{array}{l}\text { TUB-001752 } \\
\text { http://id.snsb.info/sns } \\
\text { b/collection/20919/2 } \\
\text { 9698/20739 }\end{array}$ & An early specimen from East Africa. \\
\hline Oxalis corniculata $\mathrm{L}$. & Wilhelm Schimper & S.n. & $1837-06$ & Ethiopia & $\begin{array}{l}\text { TUB-001748 } \\
\text { http://id.snsb.info/sns } \\
\text { b/collection/112371/ } \\
\text { 171149/113437 }\end{array}$ & An early specimen from East Africa. \\
\hline Oxalis corniculata $\mathrm{L}$. & Carlo L.G. Bertero & 494 & $1827-1830$ & Chili & MO-1063304 & An early specimen from South Americe \\
\hline Oxalis corniculata $\mathrm{L}$ & $\begin{array}{l}\text { Prince Maximilian } \\
\text { of Wied-Neuwied }\end{array}$ & s.n. & Dec, 1815 & Brazil & M-0153326 & $\begin{array}{l}\text { An early specimen from South America } \\
\text { São Bento Monastery, Brazil }\end{array}$ \\
\hline Oxalis corniculata $\mathrm{L}$. & George Gardner & 345 & Aug, 1837 & Brazil & MO-1063334 & $\begin{array}{l}\text { An early specimen from South America } \\
\text { Cultivated. }\end{array}$ \\
\hline Oxalis corniculata $\mathrm{L}$. & Pehr Osbeck & s.n. & 1751 & China & SBT:H:2.4.9.67 & An early specimen from China. \\
\hline
\end{tabular}

